\title{
A New Challenge to College English Teachers - - Transformation from Basic English Teaching to EAP and EOP Teaching
}

\author{
Xiangfeng GUAN, Chunbo YUAN \\ Faculty of Foreign Languages of Huaiyin Institute of Technology, Huaian, Jiangsu 223003, China \\ guanxiangfeng01@126.com, ycbdavid@ sina.com
}

\begin{abstract}
According to College English Teaching Guidance, college English will transform from basic English to EAP and EOP. First, as for each university and college, they should arrange these courses, select proper textbooks and organize the examinations from their unique characteristics. Second, as college English teachers, we should arm ourselves with scientific and technological knowledge beforehand, familiarize ourselves with scientific documents, improve our teaching skills in this new field.

Index Terms - College English Teaching Guidance; general academic English; specific academic English; English for occupation purpose
\end{abstract}

\section{Introduction}

Following a decade of college English teaching reform from 2003 to 2013 sponsored by the Department of Higher Learning of National Ministry of Education, it will launch a new round of college English teaching reform from 2014 to 2024. What are the focuses of two decades of college English reforms? According to the College English Teaching Guidance, in the first decade of college English teaching reform, its main focus was on the improvement of college students' abilities in listening, speaking and reading comprehension, projecting listening and speaking training. In the second decade of college English teaching reform, its focus has transformed to EAP (English for Academic Purpose) and EOP (English for Occupation Purpose) teaching. Without doubt, this is an important and necessary transformation; meanwhile, it has launched a new challenge to college English teachers.

\section{College English Teaching Guidance \& Its Characteristics}

\subsection{College English Teaching Guidance}

College English Teaching Guidance is a very detailed document, it consists of 9 chapters : 1) preface 2) location and characteristics of college English course 3) teaching objectives and requirements 4) arrangement of college English courses 5) evaluation and examinations 6) teaching methodology and media 7) teaching resources 8) teaching management 9) teachers' development [1]. In this guiding document, it has put forward teaching requirements for three teaching goals: 1) basic goal for the majority of college students (high school English level 7); 2) raising goal for college students with fairly well English (high school English level 8); 3) developing goal for college students with excellent English (high school English level 9). In particular, it has put forward the arrangement of college English courses in different stages:
EGP (English for General Purpose); EAP (English for Academic Purpose) and ESP (English for Specific Purpose) ; courses for cross-culture communications.

\subsection{Characteristics of College English Teaching Guidance}

Although College English Teaching Guidance is still in its discussion stage, it has provoked heated discussions and even debates among famous scholars, educators, college English teachers and college students. To sum up .I think it has the following characteristics:

\subsubsection{Projecting EAP and EOP teaching}

College English has been EGP for many years, projecting language usages, grammar, culture and the improvement of basic skills in listening, speaking, reading, writing and translating. Most college English teachers are satisfied with their proficiency in English skills, so it has never come to their minds they will teach EAP and EOP.

2.2.2 Equal emphasis on English language's humanities and academic means

English has been regarded as one course belonging to the humanities; its teaching content surrounds literature, culture, language etc. Most English texts both in high schools and colleges are adapted from English classical literature works. In other words, English course has been one of courses in the humanities. It is a new thing to be academic means to college English teachers.

2.2.3 Each college and university has more power to make their teaching plan

College English teaching has been managed by the Department of Higher Learning of National Ministry of Education for nearly 30 years, including the selection of college English textbooks, teaching objectives, arrangement of courses, teaching methodology, evaluation and examinations, even teaching hours and students' English course credits are strictly managed by the organization above. To be honest, strict management has enhanced college English course position and college English teachers' position. All the college students have benefited a lot from its strict management. Most evident performance is the ratio of college students passing CET4 (College English Test, Band 4) and CET 6 (College English Test, Band 6). College English Teaching Guidance has given more power to each college and university to select their teaching plan according to their own characteristics. 
2.2.4 EAP teaching will make preparations for college graduates in their future careers and provide opportunity to further their study abroad

Academic English, as domestic and foreign scholars define: "The use of English in the professional books, is related to the language features of majors", "language teachers and students use to learn new knowledge and skills, describe abstract concepts, and develop the students' conceptual understanding", "language used in academic research articles" [2]. To some extent, EAP teaching is not only beneficial to college graduates in their future careers, but also provide more opportunities to further their study abroad.

\section{Different Perspectives from Famous Scholars, College English Teachers and College Students}

\subsection{Perspectives from Famous Scholars and College English Teachers}

College English teaching content must be restructured, transforming from EGP to ESP[3].College English teaching must be adjusted, from the present objective of basic English teaching to EAP teaching so as to provide service for major knowledge learning [4].As the preparatory and transforming stage, EGP is quite necessary for freshmen. EAP teaching is not necessary and should not be "one size fits all" and can't be directly linked to high school English teaching [5].

As a college English teacher myself, I discuss EAP and EOP teaching with my colleagues. On the one hand, most of my colleagues think college English is very important and necessary for freshmen, because most freshmen are poor at five basic skills (listening, speaking, reading, writing and translating). On the other hand, most colleagues think EAP and EOP will not replace EGP. The proper time to teach EAP and EOP is in the second and third year at college on the condition that CET4 and CET 6 should be cancelled.

\subsection{Perspectives from College Students}

Most college students welcome this teaching reform. They think they will benefit a lot from EAP and EOP teaching, which will help their future career development and their further study abroad, but some college students who are poor at English are very worried about their English learning, because EAP and EOP are more difficult to learn, they feel afraid they will fail to pass EAP and EOP examinations.

\section{Meet the Challenge for the Sake of Students}

4.1 What Does EAP consist of?

Academic English can be subdivided into general academic English (English for general academic purpose) and specific academic English (English for specific academic purpose) two categories. General academic English emphasizes academic English learning skills and practice, including the cultivation of comprehensive learning skills to read, write, take notes when attending academic lectures, make academic reports and consult academic English documents relevant to students' majors. ESP, as it indicates, emphasizes language learning, including vocabulary, grammar, contexts and different types of academic essays [6].

4.2 College English Teachers should have Further Study to meet the Challenge

Regardless of all the difficulties and challenges, college English teachers should have further study to get to know some scientific and technological vocabulary, grammar and contexts and read some scientific and technological documents which are not familiar with them. As for the skills in general academic English, I think it is not difficult as we imagine. As long as we make our efforts, difficulties and challenges will become motivation.

\section{Conclusion}

In brief, now that ESP and EOP are beneficial to our students' future career development and will provide more opportunities to further their study abroad, our college English teachers should spare no efforts to arm ourselves with scientific and technological knowledge, read more scientific and technological documents and improve our teaching skills in this new field.

\section{Acknowledgment}

Thanks are due to Professor Shouren Wang for his assistance in writing this essay.

\section{References}

[1] Department of Higher Learning of National Ministry of Education, College English Teaching Guidance: 1-16. 2014. Unpublished.

[2] Shuhui Xiong, Weicheng Zou, What Is Academic English? How to Teach It? J. Foreign Languages in China (2): 54-64. 2012

[3] Shanghai College English Teaching Guiding Committee for University and College, Referential Frame of College English Teaching for Shanghai City (Trial implementation). Higher Education Publishing House: 2013.

[4] JigangCai, Evidence for the Vanishing of College English in China and Trend Analyses. J. .Foreign Language Research, (3): 46-52. 2012.

[5] Shouren Wang, Chenghe Ya, .Reflect on Academic Teaching J. Foreign Languages in China, (5): 5-10. 2013.

[6] Jordan, R. R. M English for Academic Purposes. Cambridge University Press, 1997. 